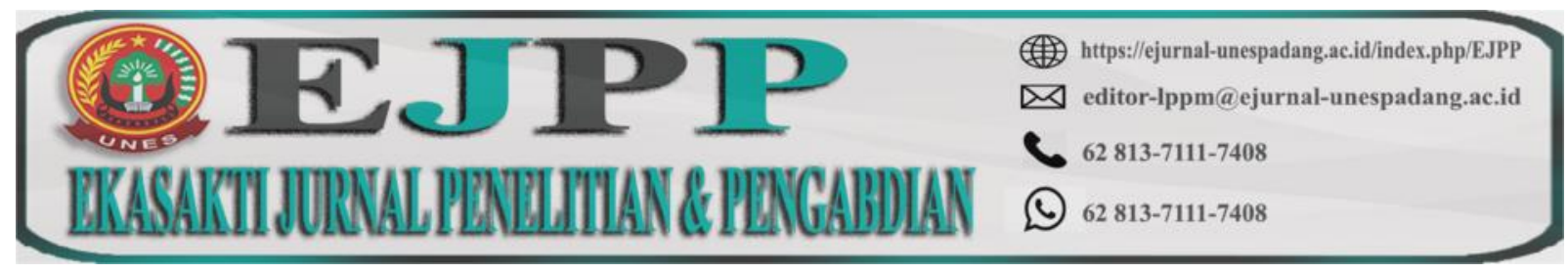

DOI: https://doi.org/10.31933/ejpp.v1i1

Received: 27/09/2020, Revised: 05/10/20, Publish: 22/11/2020

\title{
PENGARUH USIA, UKURAN, DAN INDEPENDEN DEWAN KOMISARIS TERHADAP AGRESIVENSI PAJAK
}

\author{
Yessi Rinanda ${ }^{1}$, dan Yuli Ardian ${ }^{2}$ \\ ${ }^{1)}$ Program studi Akuntansi, Akademi Akuntansi Indonesia Padang. \\ Email: yessi.rinanda17@gmail.com \\ 2) Program studi Akuntansi, Akademi Akuntansi Indonesia Padang. \\ Email: yuliardiany@gmail.com
}

\begin{abstract}
ABSTRAK
Tujuan dari penelitian ini adalah untuk menguji pengaruh Umur, Ukuran, dan Independensi Dewan Komisaris terhadap Agresivitas Pajak. Usia dewan komisaris, ukuran dewan komisaris, dan independen dewan komisaris digunakan sebagai variabel independen dan agresivitas pajak (PPA) digunakan sebagai variabel dependen. Dan dua variabel yang digunakan sebagai variabel kontrol adalah Return On Assets (ROA) dan Leverage. Data dari laporan keuangan dan laporan tahunan tahun 2011 sampai dengan 2017. Sampel penelitian ini adalah 266 perusahaan yang terdaftar di Bursa Efek Indonesia. Hasil penelitian menunjukkan bahwa Umur, Ukuran, dan Independensi Dewan Komisaris berpengaruh negatif dan signifikan terhadap Agresivitas Pajak (ETR). Return On Assets (ROA) berpengaruh positif dan signifikan terhadap Tax Aggressiveness (ETR). Sedangkan Leverage berpengaruh tidak signifikan terhadap Agresivitas Pajak (ETR).
\end{abstract}

Kata Kunci: Usia Dewan Komisaris, Ukuran Dewan Komisaris, Independensi Dewan Komisaris, Agresivitas Pajak, Return On Assets, Leverage.

\begin{abstract}
The objective of this research is to examine the effect of Age, Size, and Board of commissioners independent on Tax aggressiveness. Age of the board of commissioners, Size of the board of commissioners, and Board of commissioners independent are used as independent variable and Tax aggressiveness (ETR) are used as dependent variable. And two variables are used as control variables is Return On Assets (ROA) and Leverage. Data from the financial statements and annual report for 2011 until 2017. The sample of this research is 266 companies listed in Indonesia Stock Exchange. The results shows that Age, Size, and Board of commissioners independent has a negative and significant effect on Tax aggressiveness (ETR). Return On Assets (ROA) has positif and significant effect on Tax aggressiveness (ETR). While Leverage has not significant effect on Tax aggressiveness (ETR).
\end{abstract}


Keywords: Age of the board of commissioners, Size of the board of commissioners, Board of commissioners independent, Tax aggressiveness, Return On Assets, Leverage.

\section{PENDAHULUAN}

Perkembangan dunia bisnis sejauh ini mengalami peningkatan yang cukup pesat. Bisnis yang dilakukan mencakupi semua bidang dengan memanfaatkan sumber daya yang ada, terutama di Indonesia yang mempunyai banyak kekayaan alam yang bisa diolah dan dijadikan ladang bagi para pebisnis, dengan meningkatnya kegiatan ini berdampak bagus bagi negara, dikarenakan pembayaran pajak akan meningkat dan pendapatan negara untuk mensejahterakan masyarakat akan berjalan dengan lancar. Sumber dari pendapatan negara yang paling besar salah satunya berasal dari penyetoran wajib kepada negara yaitu melalui pajak.

Menurut Undang-Undang Republik Indonesia Nomor 16 tahun 2009 Pasal 23A, Pajak merupakan setoran wajib yang dikenakan pada orang pribadi atau badan usaha bersifat memaksa berdasarkan undang-undang. Sedangkan berdasarkan Undang-Undang Nomor 28 Tahun 2007, tentang ketentuan umum dan tata cara perpajakan menyatakan bahwa pajak adalah konstribusi wajib kepada negara yang terutang oleh orang pribadi atau badan yang bersifat memaksa dengan tidak mendapatkan imbalan secara langsung dan digunakan untuk keperluan negara bagi sebesar besarnya untuk kesejahteraan rakyat.

Kementerian Keuangan (Kemenkeu) melalui Direktorat Jenderal Pajak mencatat penerimaan pajak mencapai Rp 760,57 triliun sampai tanggal 20 Agustus 2018. Realisasi ini setara 53,41 persen dari target tahun 2018 sebesar Rp 1.424 triliun. Direktur Jenderal Pajak Robert Pakpahan menyatakan, jumlah penerimaan pajak tersebut naik 10,68 persen dari posisi penerimaan tanggal 31 Juli 2018. Kemudian bila dibandingkan periode yang sama tahun 2017 angka tersebut juga naik sebesar 15,49 persen (www.liputan6.com, 2018). Dengan ini dapat dilihat bahwasannya adanya peningkatan yang terjadi penerimaan di bidang perpajakan, akan tetapi pencapaian ini belum mencapai angka $100 \%$, dikarenakan masih adanya pelanggaran yang dilakukan oleh wajib pajak dalam melakukan tindakan pembayaran pajak, pelanggaran yang terjadi disebabkan adanya tax agresiveness yang dilakukan perusahaan.

Tujuan dilakukannya tax agresiveness pada perusahaan adalah menghindari pembayaran pajak atau membuat rendah beban pajak yang dibayarkan. Beban pajak yang dipikul oleh subyek pajak badan memerlukan perencanaan yang baik, dan oleh sebab itu strategi perpajakan menjadi mutlak diperlukan untuk mencapai perusahaan yang optimal. Wahab, et al (2017) menyatakan agresivitas pajak akan berkurang dengan adanya sistem tata kelola perusahaan dengan baik. Tax agresiveness dilakukan oleh perusahaan agar laba dari perusahaan tidak berkurang, sehingga perusahaan akan berusaha untuk melakukan penghindaran pajak dengan resiko yang kecil.

Berdasarkan temuan Halioui, Neifar and Abdelaziz (2016), adanya pengaruh besar dari struktur tata kelola perusahaan dalam terjadinya tax aggresiveness. Perusahaan melakukan tindakan tax aggresiveness untuk meminimalkan pembayaran pajak yang harus dibayar oleh perusahaan. Tindakan tax aggresiveness memiliki citra negatif di masyarakat dan juga pemerintah. 
Tax aggresiveness akan berpengaruh besar pada laba perusahaan (Dewi dan Wirawati 2017). Dengan adanya penghindaran pajak yang terjadi di kalangan perusahaan yang sudah go public, diharapkannya peran petinggi untuk melakukan kegiatan penghindaran pajak yang sesuai dengan aturan yang telah ditetapkan oleh pemerintah, para petinggi dari perusahaan yang memiliki andil cukup besar yaitu board of commissioners (Dewan komisaris).

Beberapa hal yang mempengaruhi board of commissioners dalam melakukan tindakan untuk mengawasi perusahaan diantaranya age, size, dan independent. Ibrahim, and Hanefah (2016) menemukan bukti bahwa adanya hubungan positif yang terjadi dengan tingkat usia dari board of commissioners terhadap pengambilan keputusan.

Age dari jajaran board of commissioners sangat berpengaruh terhadap kinerja dari perusahaan. Kagzi and Guha (2018) berpendapat bahwasanya age of board commissioners berpengaruh positif terhadap kinerja perusahaan. Semakin matangnya age of board of commissioners menentukan keputusan yang akan diambilnya terutama dalam melakukan kegiatan tax aggresiveness, age and experience yang matang dapat melakukan kegiatan pengawasan terhadap tax aggresiveness dengan aturan yang telah ditetapkan pemerintah.

Menurut Alqatamin, Aribi, and Arun (2017) adanya hubungan yang terjadi antara age dalam upaya meningkatkan laba perusahaan. Pekerja yang berumur tua lebih siap untuk menghadapi situasi yang mengancam perusahaan (Kahar, 2016). Karena mereka lebih memiliki pengalaman yang banyak dibandingkan dengan usia yang muda. Disamping adanya peran age of board commissioners dalam melakukan pengawasan pada sebuah perusahaan, size of board commissioners juga mempengaruhi dari pengambilan keputusan dalam melakukan tax aggresiveness. Size of board commissioners akan menentukan bagaimana komunikasi yang terjalin sesama dewan pengawas pada sebuah perusahaan. Orozco, Vargas, and Dorado (2018) menyatakan perusahaan dengan size board of commissioners yang banyak merupakan perusahaan besar reputasinya.

Dalam penelitian yang dilakukan Restu, dkk (2017) mengatakan bahwa size board commissioners berpengaruh positif terhadap kegiatan perusahaan. Dengan adanya size board of commissioners berdampak positif bagi perusahaan dalam melakukan pengawasan terhadap keberlangsungan yang terjadi pada perusahaan sehingga resiko terjadinya kecurangan dalam kegiatan tax aggresiveness sangat kecil kemungkinannya akan terjadi. Tarus and Ayabei (2016) perusahaan dengan size board of commissioners yang lebih kecil maka akan memiliki pengaruh yang lebih besar terhadap kinerja perusahaan. Di samping dalam pengawasan faktor yang dipertimbangkan lagi adalah independence board of commissioners itu tersendiri.

Menurut Hamdan and Mubarak (2017) direktur internal lebih efektif dalam meningkatkan kinerja perusahaan daripada board of commissioners independent. Kinerja perusahaan akan menjadi bagus dengan adanya upaya yang dilakukan oleh board of commissioners independent dalam melakukan tindakan tax aggresiveness yang benar sesuai aturan perpajakan yang ada di Indonesia. Dengan adanya suatu keputusan yang tepat dilakukan maka kinerja dari perusahaan akan tetap stabil bahkan mengalami peningkatan sekalipun dengan mentaati aturan yang ada. 
Virk (2017) pelanggaran tidak akan terjadi pada sebuah perusahaan kalau sebagian besar board of commissioners independent tidak memiliki janji dengan perusahaan lain

Menurut Dah, Jizi, Sbeity (2018) menemukan secara signifikan board of commissioners independent memiliki dampak positif terhadap kompensasi manajerial. Board of commissioners independent membantu perusahaan dalam melakukan perencanaan strategi jangka panjang dan secara berkala meninjau implementasi strategi dan mengurangi tindakan penghindaran pajak (Tandean and Winnie, 2016).

\section{METODE PENELITIAN}

\section{Populasi dan Sampel}

Menurut Sugiyono (2016), populasi adalah wilayah generalisasi yang terdiri atas obyek/subyek yang mempunyai kualitas dan karakteristik tertentu yang ditetapkan oleh peneliti untuk dipelajari dan kemudian ditarik kesimpulannya. Populasi yang akan menjadi pengamatan dalam penelitian ini adalah perusahaan go public yang terdaftar di Bursa Efek Indonesia pada tahun 2011-2017 terdaftar sebanyak 442 perusahaan.

Sampel merupakan bagian dari populasi yang ingin diteliti oleh peneliti. Menurut Sugiyono (2016) sampel adalah bagian dari jumlah dan karakteristik yang dimiliki oleh populasi tersebut. Bila populasi besar, dan peneliti tidak mungkin mempelajari semua yang ada pada populasi, misalnya karena keterbatasan dana, tenaga dan waktu, maka peneliti dapat menggunakan sampel yang diambil dari populasi itu. Apa yang diambil dari sampel itu, kesimpulannya akan dapat diberlakukan untuk populasi. Untuk itu sampel yang diambil dari populasi harus betul-betul representatif (mewakili). Sampel yang digunakan dalam penelitian ini adalah perusahaan go public yang terdaftar di Bursa Efek Indonesia (BEI). Pemilihan sampel dalam penelitian ini menggunakan metode random sampling. Sugiyono (2016) random sampling adalah teknik pengambilan sampel dari anggota populasi yang dilakukan secara acak tanpa memeperhatikan strata yang ada dalam populasi.

\section{Pengukuran Variabel}

\section{Tax Aggressiveness}

Dependent variabel atau variabel terikat adalah variabel yang dipengaruhi atau yang menjadi akibat, karena adanya variabel bebas (Sugiyono, 2016). Variabel dependent yang digunakan pada penelitian ini adalah tax aggressiveness (Y). Indarjati dkk, (2016) tax aggressiveness merupakan sebagai tindakan manipulasi terhadap Penghasilan Kena Pajak melalui tindakan perencanaan pajak, baik dengan cara tergolong legal (tax avoidance) ataupun ilegal (tax evasion). Tax aggressiveness dilakukan oleh wajib pajak badan untuk meminimalkan pembayaran pajak sehingga laba yang dihasilkan pada perusahaan akan menjadi meningkat. Tax aggresiveness akan berpengaruh besar pada laba perusahaan (Dewi dan Wirawati 2017). 
Dalam penelitian ini Tax aggressivenes diukur dengan menggunakan alat ukur ETR (Effective Tax Rate) dari laporan yang disediakan perusahaan yaitu dengan menggunakan rumus:

$$
E=\frac{B \quad P \quad P \quad h a}{L \quad S \epsilon \quad P}
$$

\section{Age Of The Board Of Commissioners}

Age merupakan suatu hal yang mendasari bagi seorang board of commisioners dalam melakukan tindakan atau pengawasan terhadap perusahaan yang diawasi. Kagzi, and Guha (2018) berpendapat bahwasanya age of the board of commissioners berpengaruh positif terhadap kinerja perusahaan.

Kahar (2016), hubungan antara usia dan kinerja pekerjaan kemungkinan akan menjadi masalah yang lebih penting selama dekade mendatang. Para pekerja yang lebih tua memiliki kualitas positif pada pekerjaan mereka, khususnya pengalaman, penilaian, etika kerja yang kuat, dan komitmen terhadap kualitas perusahaan. Pada penelitian ini age diukur dengan mencari ratarata umur dari board of commisioners dari perusahaan, atau dengan rumus.

Keterangan:

$$
\text { RUDK }=\frac{\text { TUDK }}{\text { BDK }}
$$

RUDK = Rata-rata Umur Dewan Komisaris

TUDK $=$ Total Umur Dewan Komisaris

$\mathrm{BDK}=$ Banyaknya Dewan Komisaris

\section{Size Of The Board Of Commissioners}

Size of the board of commissioners menentukan bagaimana kinerja dari sebuah perusahaan. Orozco, Vargas, and Dorado (2018) menyatakan perusahaan dengan ukuran dewan yang banyak merupakan perusahaan besar reputasinya. ukuran dewan komisaris berpengaruh positif terhadap kegiatan perusahaan (Restu dkk, 2017) Size merupakan ukuran atau banyaknya dewan komisaris yang ada pada perusahaan dalam melakukan pengawasan terhadap kinerja dari perusahaan, didalam penelitian ini size diperhitungkan dengan rumus:

Keterangan:

$$
\mathrm{SBOC}=\mathrm{JDK}
$$

SBOC = Size Of The Board of Commissioners

JDK = Jumlah Dewan Komisaris

\section{Board Of Commissioners Independent}

Board of commissioners independent atau komisaris independen adalah anggota dewan komisaris yang berasal dari luar perusahaan. Virk (2017) pelanggaran tidak akan terjadi pada sebuah perusahaan kalau sebagian besar board of commissioners independent tidak memiliki janji dengan perusahaan lain. Komisaris independen membantu perusahaan dalam melakukan merencanakan strategi jangka panjang dan secara berkala meninjau implementasi strategi dan mengurangi tindakan penghindaran pajak (Tandean and Winnie, 2016). Dalam variabel ini diukur dengan menggunakan rumus: 
Keterangan:

$$
\mathrm{INDK}=\frac{\mathrm{JIDK}}{\mathrm{JDK}}
$$

INDK: Independen Dewan Komisaris

JIDK : Jumlah Independen Dewan Komisaris

JDK : Jumlah Dewan Komisaris

\section{Return On Assets (ROA)}

ROA adalah perbandingan antara laba bersih dengan total aset pada akhir periode, yang digunakan sebagai indikator kemampuan perusahaan dalam menghasilkan laba, dengan menggunakan rumus sebagai berikut :

\section{Leverage}

$$
\text { ROA }=\frac{\text { Laba Sebelum Pajak }}{\text { Total Aset }}
$$

Leverage adalah penggunaan aktiva dan sumber dana oleh perusahaan yang memiliki biaya tetap (beban tetap), sumber dana berasal dari pinjaman karena memiliki bunga sebagai beban tetap (Sjahrial, 2009:147). Untuk mengukur tingkat laverage pada perusahaan dapat menggunakan rumus:

$$
L_{1} \quad=\frac{\text { Hutang }}{\text { Total Aset }}
$$

\section{HASIL DAN PEMBAHASAN}

\section{Hasil Analisis Statistik Deskriptif}

Tabel 1. Hasil Uji Statistik Deskriptif

\begin{tabular}{lcccccc} 
& ETR & Umur & Size & Inde & ROA & CL \\
\hline Mean & 0.193 & 58.266 & 4.297 & 0.409 & 3.227 & 0.556 \\
Median & 0.220 & 58.200 & 4.000 & 0.400 & 2.390 & 0.509 \\
Max & 1.340 & 80.666 & 13.00 & 0.833 & 37.200 & 11.84 \\
Min & -0.970 & 35.000 & 2.000 & 0.000 & -32.260 & -1.460 \\
Std. Dev. & 0.293 & 6.696 & 1.868 & 0.131 & 8.879 & 0.544 \\
Obs & 1862 & 1862 & 1862 & 1862 & 1862 & 1862 \\
\hline
\end{tabular}

Notes: ETR (Effective Tax Rate), Umur (Age Of The Board Of Commissioners), Size (Size Of The Board Of Commissioners), Inde (Board Of Commissioners Independent), ROA (Return On Assets), CL (Company Leverage).

Berdasarkan tabel 1 di atas menjelaskan secara deskriptif variabel- variabel dalam penelitian ini. Total observasi dalam penelitian ini sebanyak 1862, sedangkan data ETR berkisar antara -0.970 sampai 1.340 dengan nilai tengah (median) sebesar 0.220 dan untuk rata-rata (mean) sebesar 0.193 dengan standar deviasi 0.293. Data age of the board of commissioners (Umur) berkisar antara 35.000 (35) tahun sampai dengan 80.666 (80.7) tahun dengan nilai median sebesar 58.200 (58.2) tahun dan mean sebesar 58.266 (58.3) tahun dengan standard deviasi sebesar 6.696 (6.7) tahun. Untuk variabel size of the board of commissioners (Size) data yang didapatkan berkisar antara 2.000 (2) orang sampai dengan 13.000 (13) orang, dengan nilai median sebesar 4.000 (4) orang dan mean sebesar 4.297 (4) orang sedangkan untuk standard 
deviasi menunjukan angka 1.868 (1) orang. Untuk board of commissioners independent (Inde) diperoleh untuk data yang dihasilkan berkisar antara 0.000 sampai dengan 0.833 , untuk nilai median pada angka 0.400 , dan nilai mean menunjukkan pada angka 0.409 sedangkan untuk standard deviasi menunjukkan pada angka 0.131. data ROA berkisar antara $-32.260(-32.26 \%)$ sampai dengan 37.200 (37.20\%) dengan nilai median sebesar 2.390 (2.39\%) dan mean menunjukan hasil sebesar 3.227 (3.23\%) dengan standard deviasi sebesar 8.879 (8.88\%). Data company leverage (CL) berkisar antara -1.460 sampai dengan 11.846 dengan nilai tengah (median) sebesar 0.509 dan nilai rata-rata (mean) 0.556 dengan standard deviasi sebesar 0.544 .

ROA berkisar antara -73,48\% sampai 44,80\% dengan nilai tengah (median) sebesar 2,48\% dan rata-rata (mean) sebesar 2,94\% dengan standar deviasi 8,10\%., KSD berkisar antara 0,00\% sampai $1,00 \%$ dengan nilai tengah (median) sebesar $0,00 \%$ dan nilai rata-rata (mean) $0,29 \%$ dengan standar deviasi $0,45 \%$, GNDR berkisar antara $0,00 \%$ sampai $1,00 \%$ dengan nilai median sebesar $0,00 \%$ dan mean (rata-rata) sebesar 0,44\% dengan standar deviasi 0,49, AGE berkisar antara 36,67 sampai 71,00 dengan nilai median sebesar 51,20 dan mean (rata-rata) sebesar 51,15 dengan standar deviasi 5,31\%, FIRM berkisar antara 7,00 sampai 104 dengan nilai median sebesar 32,00 dan mean (rata-rata) sebesar 33,38 dengan standar deviasi 16,00 dan SIZE berkisar antara Rp. 40 (dalam milyar) sampai Rp.295.646.000 (dalam milyar) dengan nilai median sebesar Rp.4.361 (dalam milyar) dan mean (rata-rata) sebesar Rp.16.069 (dalam milyar) dengan standar deviasi sebesar Rp.34.727 (dalam milyar).

\section{Hasil Uji Asumsi Klasik}

Pengujian asumsi klasik ini menggunakan 3 uji yakni normalitas, multikolinearitas dan heteroskedastisitas. Dari hasil uji normalitas dapat diketahui bahwa Jarque-Bera adalah sebesar 2.886 dengan probability 0.236 . Karena nilai probability sebesar $0.236>0,05$ maka dapat dikatakan bahwa residual dalam model penelitian ini telah berdistribusi normal. Hasil uji mutikolinearitas didapat bahwa masing- masing independent variable dan control variable yang digunakan telah memiliki koefisien korelasi dibawah 0.80 sehingga dapat disimpulkan bahwa masing- masing independent variable dan control variable yang digunakan terbebas dari gejala multikolinearitas. Uji heteroskedastisitas nilai probability chi-squared yang dihasilkan adalah sebesar 0.199. Hasil yang diperoleh tersebut menunjukan bahwa nilai probability yang dihasilkan menunjukan $0.199>0,05$, sehingga dapat disimpulkan bahwa seluruh variabel penelitian yang akan dibentuk kedalam model regresi telah terbebas dari gejala heteroskedastisitas.

\section{Uji Hausman}

Tabel 2. Hasil Uji Hausman

\begin{tabular}{cccc}
\hline Test Summary & Chi-Sq. Statistic & Chi-Sq. d.f. & Prob. \\
\hline Cross-section random & 2.602 & 5 & 0.031 \\
\hline
\end{tabular}


Berdasarkan hasil uji pada tabel 2 dapat diketahui bahwa probability Chi-square adalah 0.031 lebih kecil dari 0.05 maka dapat disimpulkan Random Effect ditolak dan model yang digunakan sebaiknya adalah model Fixed Effect.

\section{Hasil Analisis Regresi Data Panel}

Tabel 3. Hasil Estimasi Fixed Effect Model

\begin{tabular}{lcccc}
\hline Variable & Coefficient & Std. Error & t-Statistic & Prob \\
\hline C & 0.444 & 0.808 & 0.550 & 0.582 \\
Umur & -0.438 & 0.192 & -2.280 & 0.022 \\
Size & -0.266 & 0.066 & -4.009 & 0.000 \\
Inde & -0.118 & 0.051 & -2.293 & 0.022 \\
ROA & 0.002 & 0.001 & 2.704 & 0.006 \\
CL & 0.044 & 0.057 & 0.776 & 0.437 \\
R $^{2}$ & 0.380 & & & \\
AdjR & 0.242 & & & \\
F-statistik & 0.000 & & & \\
\hline
\end{tabular}

Notes: ETR (Effectiv Tax Rate), Umur (Age Of The Board Of Commissioners), Size (Size Of The Board Of Commissioners), Inde (Board Of Commissioners Independent), ROA (Return On Assets), CL (Company Leverage).

Menggunakan analisis data panel, Tabel 3 menunjukkan temuan utama dari penelitian ini untuk model radom effect. Berdasarkan dari pengujian yang dilakukan sebelumnya didapatkan nilai koefisien regresi -0.438 dan tstatistic sebesar -2.280 dengan nilai dari probability sebesar 0.022 lebih kecil dari 0.05 maka dapat diartikan bahwasanya variable age of the board of commissioners (Umur) secara parsial berpengaruh negatif dan signifikan terhadap tax aggressiveness yang diukur mengunakan Effective Tax Rate (ETR) pada perusahaan yang terdaftar di Bursa Efek Indonesia pada tahun 2011-2017. Hasil dari penelitian ini tidak sejalan dengan penelitian yang dilakukan oleh Alqatamin, Aribi, and Arun (2017) menyatakan adanya hubungan yang terjadi antara usia dalam upaya meningkatkan laba perusahaan. Dan penelitian oleh Kahar (2016) pekerja yang berumur lebih tua akan lebih siap untuk menghadapi situasi yang mengancam perusahaan.

Variabel berikutnya adalah Size Of The Board Of Commissioners (Size). Hasil dari pengujian yang dilakukan sebelumnya didapatkan nilai koefisien regresi -0.266 dan tstatistic sebesar -4.009 dengan nilai dari probability sebesar 0.000 lebih kecil dari 0.05 dan dapat diartikan bahwa variable size of the board of commissioners secara parsial berpengaruh negatif dan signifikan terhadap tax aggressiveness yang diukur mengunakan Effective Tax Rate (ETR) pada perusahaan yang terdaftar di Bursa Efek Indonesia pada tahun 2011-2017. Hasil penelitian ini bertolak belakang dengan hasil penelitian dari Restu, dkk (2017), dan Tarus and Ayabei (2016) menyatakan bahwa size of the board of commissioners berpengaruh positif terhadap tax aggressiveness. Dan pada penelitian sebelumnya belum ada ditemukan size of the board of commissioners berpengaruh negatif dan signifikan terhadap tax aggressiveness.

Variabel ketiga adalah Board Of Commissioners Independent (Inde). Berdasarkan dari pengujian yang dilakukan sebelumnya didapatkan nilai koefisien regresi -0.118 dan $t_{\text {statistic }}$ sebesar -2.293 dengan nilai dari probibality sebesar 0.022 lebih kecil dari 0.05 dan dapat 
diartikan bahwa variable board of commissioners independent secara parsial berpengaruh negatif dan signifikan terhadap tax aggressiveness yang diukur mengunakan Effective Tax Rate (ETR) pada perusahaan yang terdaftar di Bursa Efek Indonesia pada tahun 2011-2017. Hasil ini betolak belakang dengan penelitian sebelumnya yang pernah dilakukan oleh Adestian (2015) dan Hamdan, and Mubarak (2017) yang menemukan hubungan positif terjadi antara board of commissioners independent terhadap tax aggressiveness. Dan penelitian ini mendukung penelitian yang dilakukan oleh Fadli (2016) yang menyatakan proporsi board of commissioners independent berpengaruh negatif terhadap tax aggressiveness.

Variabel kontrol yang dipakai dalam penelitian ini yaitu ROA (Return On Assets) dan CL (Company Leverage) dimana pada variabel ROA ditemukan hasil dari pengujian terhadap regresi, koefisien regresi 0.002 dan tstatistic sebesar 2.704 dengan nilai dari probitabilitas sebesar 0.006 lebih kecil dari 0.05 dan dapat diartikan bahwa control variabel Return On Asset (ROA) secara parsial berpengaruh positif dan signifikan terhadap tax aggressiveness yang diukur mengunakan Effective Tax Rate (ETR) pada perusahaan yang terdaftar di Bursa Efek Indonesia pada tahun 2011-2017. Hasil ini bertolak belakang dengan penelitian yang dilakukan oleh Maharani, Suardana (2014), Cahyono, dkk (2016), dan Meilani, Amboningtyas (2017) yang menyatakan bahwa tidak adanya pengaruh yang terjadi dari ROA terhadap tax aggressiveness, sedangkan penelitian yang dilakukan oleh Damayanti, Susanto (2015) memiliki kesamaan dari penelitian yang dilakukan ini yaitu menyatakan terdapatnya pengaruh dari ROA terhadap tax aggressiveness.

Kemudian untuk variabel CL didapatkan nilai koefisien regresi koefisien regresi 0.044 dan tstatistic sebesar 0.776 dengan nilai dari profitabilitas sebesar 0.437 lebih besar dari 0.05 dan dapat disimpulkan bahwa variabel control Company Leverage (CL) secara parsial tidak berpengaruh signifikan terhadap tax aggressiveness yang di ukur dengan menggunakan Effectif Tax Rate (ETR) pada perusahaan yang terdaftar di Bursa Efek Indonesia pada tahun 2011-2017.

Hasil penelitian ini sejalan dengan penelitian yang dilakukan Cahyono, dkk (2016) yang menyatakan bahwa tidak adanya pengaruh yang terjadi antara company leverage terhadap tax aggressivenes. Dan hasil ini tidak sejalan dengan penelitian yang dilakukan oleh Fadli (2016) yang menyatakan company leverage berpengaruh terhadap tax aggressiveness.

\section{KESIMPULAN}

Berdasarkan kepada analisis dengan pembahasan hasil pengujian hipotesis maka dapat diajukan beberapa kesimpulan penting yang merupakan inti jawaban dari masalah yang dibahas didalam penelitian ini, yaitu Age, Size, dan board of commissioners independent berpengaruh negatif dan signifikan terhadap Tax aggresiveness (ETR). dan Return On Assets (ROA) berpengaruh positif dan signifikan terhadap Tax aggressiveness (ETR). Sedangkan Leverage tidak berpengaruh signifikan terhadap Tax aggressiveness (ETR) Hasil ini menunjukan bahwa tax aggressiveness pada perusahaan akan dapat menurun kalau kinerja dari board of commissioners dapat berjalan dengan baik. Saran bagi peneliti selanjutnya sebaiknya menambah variabel lain yang juga dapat mempengaruhi tax aggressiveness. 


\section{REFERENSI}

Adestian. 2015. Pengaruh Dewan Komisaris, Dewan Direksi, Dewan Komisaris Independen, Komite Audit Dan Ukuran Perusahaan Pada Kinerja Perusahaan Perbankan Yang Listing Di BEI Pada Tahun 2012-2014. Semarang : Universitas Dian Nuswantoro.

Adriani, P.J.A. 2014. Akuntansi Pajak. Jakarta: Salemba Empat.

Alqatamin, Aribi, Arun. 2017. The Effect Of The CEO's Characteristics on EM: Evidence F rom Jordan. University of Central Lancashire. International Journal Of Accounting \& Information Management Vol. 25, No. 3, Page. 356-375.

Boharai. 2002. Pengantar Hukum Pajak. Jakarta: PT. Raja Grafindo Persada.

Cahyono, dkk. 2016. Pengaruh Komite Audit, Kepemilikan Institusional, Dewan Komisaris, Ukuran Perusahaan (SIZE), Leverage (DER), Dan Profitabilitas (ROA) Terhadap Tindakan Penghindaran Pajak (Tax Avoidance) Pada Perusahaan Perbankan Yang Listing BEI Periode Tahun 2013-2013. Universitas Padjajaran. Journal Of Accounting Vol. 2, No. 2, Hal. 182-208.

Dah, Jizi, Sbeity. 2018. Board Independence and Managerial Authority. Lebanese American University. International Journal Vol. 25, No. 3, Page. 838-853.

Damayanti, Susanto. 2015. Pengaruh Komite Audit, Kualitas Audit, Kepemilikan Institusional, Resiko Perusahaan Dan Return On Assets Terhadap Tax Avoidance. UIN Syarif Hidayatullah Jakarta. Jurnal Bisnis dan Manajemen Vol. 5, No. 2, Hal. 187-206.

Dermawan Sjahrial. 2009. Manajemen Keuangan Edisi 3. Jakarta: Mitra Wacana Media.

Dewi, Wirawati. 2017. Pengaruh Agresivitas Pajak Pada Corporate Social Responbility Dengan Likuiditas Sebagai Variabel Pemoderasi. Universitas Udayana. E-Jurnal Akuntansi Vol. 19, No. 3, Hal. 1943-1969.

Effendi Arief. 2016. The Power of Good Corporate Governance Edisi 2. Jakarta Selatan: Salemba Empat.

Fadli. 2016. Pengaruh Likuiditas, Leverage, Komisaris Independen, Manajemen Laba, dan Kepemilikan Institusional Terhadap Agresivitas Pajak Perusahaan (Studi Kasus Perusahaan Manufaktur yang Terdaftar di Bursa Efek Indonesia periode 2011-2013). Universitas Riau. Jurnal Fakultas Ekonom Vol. 2, No. 1, Hal: 1205-1219.

Ghozali, Imam. 2013. Aplikasi Analisis Multivariate dengan program SPSS, Edisi Ketujuh. Semarang: Badan Penerbit Universitas Diponegoro.

Gujarati, Damodar. 2015. Dasar-dasar Ekonometrika Edisi Kelima Buku 1. Jakarta Timur: Erlangga.

Halioui, Neifar, Abdelaziz. 2016. Corporate Governance, CEO Compensation and Tax Aggressiveness Evidence From American Firms Listed On The NASDAQ 100. Al-Imam 
Muhammad Ibn Saud Islamic University. Review Of Accounting and Finance Vol. 15, No. 4, Page. 445-462.

Hamdan, Al Mubarak. 2017. The Impact Of Board Independence On Accounting-Based Performance Evidence From Saudi Arabia and Bahrain. Ahlia University. Journal Of Economics and Administrative Sciences Vol. 33, No. 2, Page. 114-130.

Heriyanti. 2018. The Effect of Capital Structure, Controlling Shareholder and Forign Ownership on Corporate Performance. Skripsi. Universitas Putra Indonesia "YPTK".

Ibrahim, Hanefah. 2016. Board Diversity and Corporate Social Responbility in Jordan. Universiti Sains Islam Malaysia. Journal Of Financial Reporting and Accounting Vol. 14, No. 2, Page. 279-298.

Indarjati, Djumena, Yuniarwati. 2016. Faktor-Faktor Yang Mempengaruhi Agresivitas Pajak Pada Perusahaan Manufaktur Yang Terdaftar Di BEI 2013-2015. Universitas Tarumanagara. Jurnal Muara Ilmu Ekonomi dan Bisnis Vol. 1, No. 1, Hal. 125-134.

Kagzi, Guha. 2018. Does Board Demographic Diversity Influence Firm Performance? Evidence from Indian-Knowledge Intensive Firms. Indian Institute of Management Rohtak. International Journal Vol. 25, No. 3, Page. 1028-1058.

Kahar. 2016. Pengaruh Age Diversity, Gender Diversity dan Occupational Heterogeneity Terhadap Financial Performance Bank Umum di Indonesia. Jakarta : STIE Indonesia Banking School.

Kholis. 2014. Analisis Struktur Kepemilikan dan Perannya Terhadap Praktik Manajemen Laba Perusahaan. STMIK El Rahma Yogyakarta. Jurnal ADDIN Vol. 8, No. 1, Hal. 203-222.

Maharani, Suardana. 2014. Pengaruh Corporate Governance, Profitabilitas Dan Karakteristik Eksekutif Pada Tax Avoidance Perusahaan Manufaktur. Universitas Udayana. E-Jurnal Akuntansi Vol. 9, No. 2, Hal. 525-539.

Mahulete, Ummi K. 2016. Pengaruh DAU dan PAD terhadap Belanja Modal di Kabupaten/Kota Provinsi Maluku. Skripsi. Universitas Muhammadyah Malang.

Mardiasmo. 2011. Perpajakan Edisi Revisi 2011. Yogyakarta: CV Andi.

Meilani, Amboningtyas. 2017. Analisis Pengaruh Rasio Likuiditas, Leverage, Dan Profitabilitas Terhadap Dividend Payout Ratio (DPR) Dengan Firm Size Sebagai Variabel Intervening Pada Perusahaan Manufaktur Yang Terdaftar Di Bursa Efek Indonesia Periode Tahun 2012-2016. Semarang: Universitas Pandanaran Semarang.

Nurcahyo. 2014. Pengaruh Struktur Kepemilikan Saham Dan Ukuran Perusahaan Terhadap Kinerja Perusahaan (Studi Empiris pada Perusahaan Manufaktur yang terdaftar di BEI tahun 2010-2013). Skripsi Program Sarjana Fakultas Ekonomika dan Bisnis. Semarang : Uniiversitas Diponegoro. 
Nuryanto, Pambuko. 2018. Eviews untuk Analisis Ekonometrika Dasar: Aplikasi dan Interprestasi. Magelang: UNIMA PRESS.

Orozco, Vargas, Dorado. 2018. Trends On The Relationship Between Board Size and Financial and Reputational Corporate Performance The Colombian Case. University Of Madrid, University Externado de Colombia. European Journal Of Management and Business Economics Vol. 27, No. 2, Page. 183-197.

Otoritas Jasa Keuangan No. 32/POJK.4/2014 tentang direksi dan dewan komisaris emiten atau perusahaan publik.

Peraturan Menteri Tenaga Kerja R.I Nomor: Per.02/Men/1993 Tentang Usia Pensiun Normal Dan Batas Usia Pensiun Maksimum Bagi Peserta Peraturan Dana Pensiun.

Puasanti. 2013. Pengaruh Ukuran Perusahaan, Umur Perusahaan, Konsentrasi Kepemilikan, Komisaris Independen, dan Leverage Terhadap Tingkat Pengungkapan Modal Intelektual. Skripsi. Universitas Negeri Semarang.

Restu, Yuliyandari, Nurbaiti. 2017. Pengaruh Ukuran Dewan Komisaris, Proporsi Dewan Komisaris Independen dan Ukuran Komite Audit Terhadap Pengungkapan Corporate Social Responbility (Studi Kasus Pada Perusahaan BUMN yang Terdaftar di Bursa Efek Indonesia Periode 2013-2016). Universitas Telkom. E-Proceeding of Management Vol. 4, No. 2. Hal. 2742-2749.

Richardson, Taylor, Lanis. 2016. Women On The Board Of Directors and Corporate Tax Aggressiveness in Australia An empirical analysis. University of Adelaide. Accounting Research Journal Vol. 29, No. 3, Page. 313-331.

S.I Djajadiningrat. 2015. Asas dan Dasar Perpajakan 2. Bandung: Eresco.

Sugiyono. 2016. Metode Penelitian Kuantitatif, Kualitatif dan R\&D. Bandung: PT. Alfabet.

Susanti, Saputra, Harini. 2018. Pengaruh Diversifikasi Gender, Umur, Tenure dan Pendidikan Terhadap Profitabilitas Perusahaan Perbankan di Bursa Efek Indonesia. STKIP PGRI Sumbar. Journal of Economic and Economic Education Vol. 6, No. 2, Hal. 192-206.

Tandean, Winnie. 2016. The Effect of Good Corporate Governance on Tax Avoidance: An Empirical Study on Manufacturing Companies Listed in IDX period 2010-2013. Intitute Bussiness and Informatics Kwik Kian Gie. Asian Journal of Accounting Vol. 1, No. 1, Page. 28-38.

Tarus, Ayabei. 2016. Board Composition and Capital Structure: Evidence From Kenya. Moi University. Management Research Review Vol. 39, No. 9, Page. 1056-1079.

Thesarani. 2017. Pengaruh Ukuran Dewan Komisaris, Kepemilikan Manajerial, Kepemilikan Institusional dan Komite Audit Terhadap Struktur Modal. Universitas Negeri Yogyakarta. Jurnal Nominal Vol. VI, No. 2, Hal. 1-13. 
Undang-Undang PT No. 40 Tahun 2007 Pasal 1 Ayat 6 Tentang Perseroan Terbatas.

Undang-Undang Republik Indonesia Nomor 16 Tahun 2009 Tentang Ketentuan Umum dan Tata Cara Perpajakan.

Undang-Undang Republik Indonesia Nomor 20 Tahun 1999 Tentang Pengesahan Konvensi ILO Nomor 138 Mengenai Usia Minimum Untuk Diperbolehkan Bekerja.

Undang-Undang Republik Indonesia Nomor 28 Tahun 2007 Ketentuan Umum dan Tata Cara Perpajakan.

Virk. 2017. The Influence Of Board Characteristics On Corporate Illegality. Panjab University. Journal Of Financial Regulation and Compliance Vol. 25, No. 2, Page. 133-148.

Wahab, et al. 2017. Political Connections, Corporate Governance, and Tax Aggressiveness in Malaysia. University of Technology. Asian Review of Accounting Vol. 25, No. 3, Page. 424-451.

Widarjono, A. 2013. Ekonometrika Pengantar dan Aplikasinya Edisis 4. Yogyakarta: UPP STIM YKPN.

Winarno, Wing Wahyu. 2015. Analisis Ekonometrika dan Statistika dengan Eviews. Yogyakarta: UPP STIM YKPN.

Ying, Wright, Huang. 2017. Ownership Structure and Tax Aggressiveness Companies. Ningbo University of Technology. International Journal of Accounting \& Information Management Vol. 25, No. 3, Page. 313-332.

www.liputan6.com (accessed 23 Agustus 2018, 12.17 WIB).

www.idx.co.id

www.idxsituslama.co.id

https://www.graphpad.com diakses tanggal 15 Desember 2018/ 15.45 